Jurnal Kirana 2020 Vol. 1(1): 1-11

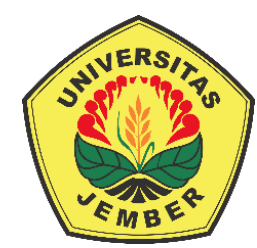

Jurnal Komunikasi dan Penyuluhan Pertanian Journal of Communication and Agricultural Extension email: jurnalkirana@unej.ac.id https://jurnal.unej.ac.id/index.php/jkrn

\title{
Proses Komunikasi dalam Penyuluhan Pertanian Program System of Rice Intensification (SRI)
}

\section{Communication Process in Agricultural Extension System of Rice Intensification (SRI) Program}

\section{Salman Ali Rusdy ${ }^{\bowtie}$ dan Aryo Fajar Sunartomo ${ }^{2}$}

${ }^{1}$ Program Studi Agribisnis Fakultas Pertanian Universitas Jember

2 Program Studi Penyuluhan Pertanian Fakultas Pertanian Universitas Jember

\begin{tabular}{|c|c|}
\hline INFO ARTIKEL & ABSTRACT \\
\hline $\begin{array}{l}\text { Diterima } 31 \text { Agu } 2020 \\
\text { Direvisi } 19 \text { Sep } 2020 \\
\text { Diterbitkan } 27 \text { Okt } 2020\end{array}$ & $\begin{array}{l}\text { Communication and development are two things that are very closely } \\
\text { related. Agricultural extension activities are one of the facilitating } \\
\text { factors for agricultural development. Agricultural extension activities } \\
\text { are a communication process where field agricultural extension agents } \\
\text { become information sources and farmers as recipients of information. }\end{array}$ \\
\hline $\begin{array}{l}\text { e-ISSN 2747-2264 } \\
\text { p-ISSN 2746-4628 } \\
\text { DOI } \\
\text { doi.org/10.19184/jkr } \\
\text { n.v1i1.20309 }\end{array}$ & $\begin{array}{l}\text { delivering information about agricultural extension. The study was } \\
\text { conducted using qualitative methods. Research location in } \\
\text { Rowotengah Village, Sumberbaru District, Jember Regency, East Java. } \\
\text { Determination of informants was determined by purposive sampling. } \\
\text { Data collection methods used are observation, interviews and } \\
\text { documentation. Data analysis used the Miles and Huberman model, } \\
\text { namely data reduction, data presentation and conclusion drawing. } \\
\text { Test the validity of the data using source triangulation. The results } \\
\text { showed that communicators in agricultural counseling were field } \\
\text { agricultural extension workers, farmers and pesticide formulator } \\
\text { officers. The message conveyed in agricultural extension is the SRI } \\
\text { planting system method which includes field schools, organic } \\
\text { fertilization, and the manufacture of MOL. The communication channels } \\
\text { used are interpersonal channels including face to face, cellphone, and }\end{array}$ \\
\hline $\begin{array}{l}\text { Keywords: } \\
\text { agricultural } \\
\text { extension, SRI } \\
\text { Program, } \\
\text { communication } \\
\text { process }\end{array}$ & $\begin{array}{l}\text { group meetings. The targets of agricultural counseling are group } \\
\text { leaders and members of farmer groups. The effect of communication } \\
\text { received from the delivery of information on agricultural extension } \\
\text { includes cognitive effects, affective effects and conative effects.. }\end{array}$ \\
\hline
\end{tabular}

$凶$ Penulis Koresponden :

E-mail : salmanali0902@gmail.com 


\begin{tabular}{|c|c|}
\hline & ABSTRAK \\
\hline & $\begin{array}{l}\text { Komunikasi dan pembangunan merupakan dua hal yang saling } \\
\text { berhubungan sangat erat. Kegiatan penyuluhan pertanian merupakan } \\
\text { salah satu faktor pelancar pembangunan pertanian. Kegiatan } \\
\text { penyuluhan pertanian adalah proses komunikasi dimana penyuluh } \\
\text { pertanian lapangan menjadi sumber informasi dan petani sebagai } \\
\text { penerima informasi. Tujuan penelitian untuk mengidentifikasi proses } \\
\text { komunikasi dalam menyampaikan informasi tentang penyuluhan } \\
\text { pertanian. Penelitian dilakukan dengan menggunakan metode } \\
\text { kualitatif. Lokasi penelitian di Desa Rowotengah Kecamatan } \\
\text { Sumberbaru Kabupaten Jember Provinsi Jawa Timur. Penentuan } \\
\text { informan ditentukan dengan cara sengaja (purposive sampling) yang } \\
\text { terdiri dari informan kunci (key informan) dan informan pendukung. } \\
\text { Metode pengumpulan data yang digunakan yaitu observasi, } \\
\text { wawancara dan dokumentasi. Analisis data menggunakan model } \\
\text { Miles and Huberman yaitu reduksi data, penyajian data dan } \\
\text { penarikan kesimpulan. Uji keabsahan data menggunakan triangulasi } \\
\text { sumber. Hasil penelitian menunjukan bahwa komunikator pada } \\
\text { penyuluhan pertanian adalah penyuluh pertanian lapangan, petani } \\
\text { dan petugas formulator pestisida. Pesan yang disampaikan dalam } \\
\text { penyuluhan pertanian adalah metode sistem tanam SRI yang meliputi } \\
\text { sekolah lapang, pemupukan organik, dan pembuatan MOL. Saluran } \\
\text { komunikasi yang digunakan yaitu saluran antar pribadimeliputitatap } \\
\text { muka, handphone, dan pertemuan kelompok. Sasaran dari } \\
\text { penyuluhan pertanian yaitu ketua kelompok beserta anggota }\end{array}$ \\
\hline $\begin{array}{l}\text { Kata kunci: } \\
\text { penyuluhan } \\
\text { pertanian, program } \\
\text { SRI, proses } \\
\text { komunikasi }\end{array}$ & $\begin{array}{l}\text { kelompok tani. Efek komunikasi yang diterima dari penyampaian } \\
\text { informasi penyuluhan pertanian yaitu meliputi efek kognitif, efek } \\
\text { afektif dan efek konatif. }\end{array}$ \\
\hline
\end{tabular}

\section{PENDAHULUAN}

Pembangunan pertanian di Indonesia masih terkendala oleh banyak faktor yang menyebabkan sulitnya petani berkembang. Salah satu upaya dalam meningkatkan produktivitas pertanian dapat dilakukan melalui kegiatan penyuluhan yang dilakukan oleh petugas penyuluh dari Balai Penyuluhan Pertanian di daerah sesuai dengan ("Undang-Undang Republik Indonesia Nomor 16 Tahun 2006 Tentang Sistem Penyuluhan Pertanian, Perikanan Dan Kehutanan (SP3K)," 2006) bahwa penyuluhan pertanian, perikanan, kehutanan yang selanjutnya disebut penyuluhan adalah proses pembelajaran bagi pelaku utama serta pelaku usaha agar mereka mau dan mampu menolong dan mengorganisasikan dirinya dalam mengakses informasi pasar, teknologi, permodalan, dan sumber daya lainnya, sebagai upaya untuk meningkatkan produktivitas, efisiensi usaha, pendapatan, dan kesejahteraannya, serta meningkatkan kesadaran dalam pelestarian fungsi lingkungan hidup.

Penyuluhan pertanian merupakan suatu sistem pendidikan di luar sekolah untuk para petani dan keluarganya dengan tujuan agar mereka mampu, sanggup dan berswadaya meningkatkan usahatani, selanjutnya mengarah ke pendapatan dan kesejahteraan mereka khususnya dan masyarakat pada umumnya. Dengan kehadiran penyuluhan, petani dapat dibina dan dibimbing dengan cara 
berkomunikasi yang baik dan tetap memberikan dorongan dan keyakinan yang kuat dalam diri petani untuk meyakini serta menerima suatu kegunaan dari hal- hal baru (Batlayeri, Adam, \& Far-Far, 2013). Penyuluhan pertanian didalam prakteknya dimaksudkan sebagai kegiatan menyampaikan informasi mengenai ilmu dan teknologi baru maupun informasi mengenai peraturan-peraturan atau kebijakan pemerintah yang perlu diketahui dan ditaati atau dilaksanakan oleh petani dan kelompok-kelompok masyarakat lain untuk mencapai tujuan pembangunan yang telah ditetapkan. Kegiatan penyuluhan pertanian adalah proses komunikasi dimana penyuluh pertanian lapangan menjadi sumber informasi dan petani sebagai penerima informasi.

Komunikasi merupakan proses pengiriman pesan atau informasi oleh komunikator atau penyuluh kepada komunikan atau petani tetapi dalam proses pengiriman tersebut dibutuhkan suatu keterampilan dalam memaknai pesan baik oleh komunikator ataupun komunikan sehingga dapat membuat sukses pertukaran informasi. Komunikasi dan metode penyuluhan yang dipakai merupakan hal terpenting dalam suatu kegiatan penyuluhan agar terciptanya kondisi yang diharapkan dari kegiatan penyuluhan tersebut. Namun dalam proses penyuluhan ini dibutuhkan keahlian dan keterampilan berkomunikasi bagi seorang penyuluh dalam mensosialisasikan program-program yang ingin dijalankan (Rasyid, 2012).

Komunikasi yang efektif terjadi apabila mempunyai pemahaman informasi yang sama antara setiap anggota kelompok dalam penerimaan informasi. Efektifitas penyuluhan melalui komunikasi dan peningkatan ketrampilan petani melalui kelompok-kelompok akan memberikan hasil yang optimal. Berkaitan dengan ini maka pemerintah telah mencanangkan program pengembangan kelembagaan kelompok yang mendapat pembinaan secara intensif dan kontinu dari pemerintah (Rintjap, 2015).

Seiring dengan kemajuan ilmu pengetahuan dan teknologi telah mendorong lahirnya inovasi atau temuan-temuan baru, termasuk di bidang pertanian. Melalui berbagai penelitian ilmiah, pada saat ini telah banyak ditemukan dan dihasilkan teknologi pertanian baru. Sebagian dari temuan teknologi itu telah didesiminasikan kepada masyarakat tani untuk meningkatkan hasil usaha taninya. Namun, sebagian dari teknologi tersebut ternyata belum atau tidak diadopsi oleh petani, meskipun berbagai upaya telah dilakukan untuk meyakinkan kemanfaatannya bagi kebutuhan peningkatan taraf hidup mereka.

Beberapa tahun terakhir, pembangunan pertanian dihadapkan pada stagnansi dalam informasi dan inovasi pertanian yang kemudian berdampak pada menurunnya optimalisasi sistem penyuluhan sejalan dengan pesatnya penetrasi produk-produk pertanian di era globalisasi ini. Model penyuluhan lama dimana penyuluh sebagai agen transfer teknologi dan informasi sudah tidak cukup. Informasi sebagai sesuatu hal yang tak ternilai harganya tentunya akan lebih mudah diakses oleh pihak-pihak yang memiliki kemampuan untuk mendapatkan akses, dalam hal ini adalah para pemilik modal dalam sektor swasta. Sisi lain, petani hanya dapat mengandalkan kapasitas penyuluh dalam mendampingi petani mengembangkan proses belajar inovasi pertanian. Baik petani maupun penyuluh sudah diupayakan untuk mendapatkan informasi tentang inovasi yang dihasilkan oleh para peneliti baik di lembaga penelitian maupun perguruan tinggi namun belum mendapatkan hasil optimal (Elian, 2015). Berkaitan dengan hal tersebut, maka 
Pemerintah membentuk kelompok tani yang didampingi oleh penyuluh pertanian untuk membantu para petani dalam meningkatkan taraf hidup petani melalui pemberdayaan petani dengan mengembangkan sumber daya manusia, program yang harus dilakukan meliputi pendidikan, keterampilan dan pekerjaan.

Berdasarkan Peraturan Menteri Pertanian Nomor 273/Kpts/OT.160/4/2007, pada tanggal 13 April 2007 tentang Pedoman Pembinaan Kelembagaan Petani. Pedoman tersebut berisi memerlukannya dukungan sumber daya manusia berkualitas melalui penyuluhan pertanian dengan pendekatan kelompok yang dapat mendukung sistem agribisnis berbasis pertanian (tanaman pangan, hortikultura, peternakan dan perkebunan). Sehubungan dengan itu perlu dilakukan pembinaan dalam rangka penumbuhan dan pengembangan kelompok tani menjadi kelompok yang kuat dan mandiri untuk meningkatkan pendapatan petani dan keluarganya. Menurut Peraturan Menteri Pertanian Nomor 82/Permentan/OT.140/8/ 2013, Kelompok tani yang selanjutnya disebut poktan adalah kumpulan petani/peternak/pekebun yang dibentuk atas dasar kesamaan kepentingan, kesamaan kondisi lingkungan sosial, ekonomi, dan sumberdaya; kesamaan komoditas, dan keakraban untuk meningkatkan dan mengembangkan usaha Pelaku utama (petani) adalah Warga Negara Indonesia perseorangan dan/atau beserta keluarganya yang melakukan usahatani di bidang tanaman pangan, hortikultura, perkebunan, dan/atau peternakan. Selanjutnya, dalam rangka meningkatkan kemampuan poktan dilakukan pembinaan dan pendampingan oleh penyuluh pertanian, dengan melaksanakan penilaian klasifikasi kemampuan poktan secara berkelanjutan yang disesuaikan dengan kondisi perkembangannya.

Kelompok tani didefinisikan sebagai sekelompok petani yang secara informal mengkondisikan diri berdasarkan kepentingan bersama dalam berusahatani. Semangat awal pembentukan kelompok tani adalah untuk memperkuat posisi tawar, terutama dalam pengadaan sarana produksi dan pemasaran hasil secara kolektif. Indonesia mempunyai pengalaman panjang pembentukan kelompok tani, sejak diluncurkannya program BIMAS, INSUS dan Supra Insus di era 1970-an dan 1980an. Saat ini, kebanyakan kelompok tani di Indonesia tidak lagi dibentuk asas inisiatif petani dalam memperkuat diri, melainkan kebanyakan merupakan respon dari program-program pemerintah yang mengharuskan petani berkelompok (Nuryanti \& Swastika, 2011).

Salah satu daerah di Kecamatan Sumberbaru yang termasuk memilik petugas penyuluhan yang sangat kooperatif dan tanggap terhadap keluhan dan laporan dari petani yaitu di Desa Rowotengah Kecamatan Sumberbaru Kabupaten Jember Provinsi Jawa Timur. Kondisi pertanian di Desa Rowotengah cukup baik karena sebagian besar wilayahnya adalah daerah pertanian yang subur apabila ditanami tanaman pangan. Pertanian di Desa Rowotengah mengalami peningkatan dengan meningkatnya hasil produksi pertaniannya. Produksi utama pertanian di Desa Rowotengah adalah padi, karena tanahnya sangat sesuai dengan karateristik jenis tanaman pangan.

Salah satu kelompok tani yang berada di Desa Rowotengah yaitu Kelompok Tani Barokah. Kelompok Tani Barokah merupakan kelompok tani yang dapat dikategorikan sebagai kelompok tani yang cepat tanggap dan antusias dalam menyerap teknologi dan inovasi terutama untuk meningkatkan produktifitas usahatani padi. Kegiatan usahatani padi yang dikembangkan oleh Kelompok Tani 
Barokah tidak bisa terlepas dari komunikasi yang dilakukan dengan baik. Komunikasi yang terjalin dengan baik mampu menimbulkan interaksi yang positif dalam pelaksanaan usahatani. Sehingga, tujuan dari komunikasi dapat tercapai dengan efektif.

Kelompok Tani Barokah juga aktif berkomunikasi dengan Penyuluh Pertanian Lapangan dalam mengenal sistem tanam SRI. Kendala yang dihadapi dalam mensosialisasikan SRI, diantaranya petani belum terbiasa menggunakan pupuk organik, belum terbentuknya regu tanam yang mampu tanam satu-satu dan kebiasaan menggunakan benih yang cukup banyak serta jarak tanam yang terlalu sempit dan ketergantungan pestisida kimia yang terlalu tinggi. Pendampingan Penyuluh Pertanian Lapangan dilakukan dari awal tanam sampai panen untuk mengatasi kendala-kendala tersebut. Kegiatan yang dilakukan diantaranya, melatih regu tanam SRI bertahap dan memberikan contoh serta memotivasi petani menggunakan pupuk organik dengan mengaplikasikan pupuk organik tersebut. Penggunaan metode SRI yang dilakukan oleh Kelompok Tani Barokah mampu menghasilkan produktivitas padi meningkat (Ratnasari, 2015).

Kelompok Tani Barokah merupakan kelompok tani mandiri yang dapat digolongkan kedalam kelompok kelas madya. Indikator berdayanya kelompok ini dilihat berdasarkan kemampuan merencanakan kegiatan untuk meningkatkan produktivitas usaha tani anggotanya serta kemampuan dalam menerapkan teknologi, pemanfaatan informasi, kerjasama kelompok dan dapat memecahkan berbagai permasalahan yang ada. Harapan kedepannya kelompok tani banyak berada pada tingkatan madya hingga utama, dimana Kelompok Tani Barokah dapat dijadikan percontohan dalam memberdayakan kelompok tani program SRI.

Melihat peningkatan produksi padi dengan metode SRI dengan varietas unggul baru dan keaktifan Kelompok Tani Barokah dalam menghadiri penyuluhan, tentu tidak lepas dari proses komunikasi dalam penyuluhan pertanian. Komunikasi merupakan suatu alat yang digunakan dalam proses kegiatan penyuluhan. Kegiatan penyuluhan pertanian merupakan kegiatan komunikasi. Sehingga, hal tersebut mendasari penelitian ini untuk melihat proses komunikasi dalam penyuluhan pertanian yang dilakukan di Kelompok Tani Barokah di Desa Rowotengah Kecamatan Sumberbaru Kabupaten Jember. Proses komunikasi ini bertujuan untuk menciptakan komunikasi yang efektif sesuai dengan tujuan komunikasi pada umumnya. Tujuan penelitian untuk mengidentifikasi proses komunikasi pada penyuluhan pertanian program System Rice of Intensification.

\section{METODE PENELITIAN}

Penentuan daerah penelitian didasarkan dengan metode sengaja (purposive method). Penelitian dilakukan di Desa Rowotengah Kecamatan Sumberbaru Kabupaten Jember Jawa Timur, atas pertimbangan bahwa di Desa Rowotengah terdapat kelompok tani dengan nama Kelompok Tani Barokah yang merupakan salah satu kelompok tani yang membudidayakan tanaman padi dengan program System of Rice Intensification dan tingkat produktivitas tergolong tinggi di Kabupaten Jember Jawa Timur. Metode yang digunakan dalam penelitin ini adalah kualitatif.

Penelitian kualitatif adalah suatu proses penelitian dan pemahaman yang berdasarkan pada metodologi yang menyelidiki suatu fenomena sosial dan masalah manusia. Penelitian kualitatif dilakukan pada kondisi alamiah dan bersifat 
penemuan. Penelitian kualitatif merupakan riset yang bersifat deskriptif dan cenderung menggunakan analisis dengan pendekatan induktif. Informan yang digunakan pada penelitian ini terdiri dari informan kunci (key informan) dan informan pendukung. Penentuan informan dalam penelitian ini ditetapkan dengan cara sengaja (purposive sampling). Informan kunci (key informan) yang dipilih yaitu ketua Kelompok Tani Barokah dan informan pendukung yaitu anggota Kelompok Tani Barokah dan penyuluh pertanian di Kelompok Tani Barokah.

Pengumpulan data yang digunakan yaitu terdiri dari tiga metode yaitu observasi, wawancara dan dokumentasi. Analisis data menggunakan analisis Miles dan Huberman, yaitu reduksi data, penyajian data, dan penarikan kesimpulan. Uji keabsahan data menggunakan triangulasi sumber. Triangulasi sumber digunakan untuk menguji kredibilitas data dilakukan dengan cara mengecek data yang telah diperoleh melalui beberapa sumber. Sumber yang diwawancarai mendalam pada penelitian ini adalah ketua kelompok tani, anggota kelompok tani, dan Penyuluh Pertanian Lapangan (PPL).

\section{HASIL DAN PEMBAHASAN}

Kegiatan penyuluhan pertanian melibatkan komunikasi antar seseorang dalam menyampaikan informasi untuk membuat suatu keputusan. Kelompok Tani Barokah merupakan salah satu bagian kecil dari sasaran kegiatan penyuluhan pertanian yang bergerak dibidang budidaya usahatani padi. Tujuan diberikannya penyuluhan pertanian kepada petani memiliki keberagaman yang ingin dicapai baik untuk perubahan jangka panjang atau jangka pendek. Kegiatan penyuluhan pertanian merupakan kegiatan proses komunikasi. Proses komunikasi dilakukan dengan beberapa tahapan yang teratur agar penyampaian pesan dari komunikator dapat diterima dengan baik oleh komunikan. Teori Harold Laswell, mengatakan bahwa cara yang baik untuk menjelaskan komunikasi ialah dengan menjawab pertanyaan sebagai berikut ; Who Says What In Which Channel to Whom with What Effect?. Paradigma Harold Lasswell menunjukan bahwa komunikasi meliputi lima unsur sebagai jawaban dari pertanyaan yang diajukan, yaitu : 1). Komunikator, 2). Pesan, 3). Media, 4). Komunikan, dan 5). Efek.

\section{Komunikator Penyuluhan Pertanian}

Komunikator adalah orang atau petugas yang tugasnya menyampaikan pesan, apakah itu pesan pembangunan dalam artian yang lebih umum atau pesan pembangunan pertanian, kepada komunikan agar pesan tersebut dapat diterima dan dilaksanakan oleh komunikan dalam melaksanakan tugasnya seharihari.Sumber informasi dapat berupa individu atau lembaga yang menciptakan informasi sebagai pesan dalam proses komunikasi. Hasil penelitian yang dilakukan di Kelompok Tani Barokah berkaitan dengan komunikator penyuluhan pertanian diantaranya yaitu :

a) Penyuluh Pertanian Lapangan (PPL)

Kegiatan penyuluhan pertanian pada kelompok tani tidak lepas dari seorang komunikator. Komunikator dalam penyuluhan pertanian yang dilakukan di anggota Kelompok Tani Barokah yaitu PPL. PPL menjadi sumber informasi yang utama dalam kegiatan penyuluhan pertanian pada kelompok tani tersebut. PPL menyampaikan informasi secara langsung kepada anggota kelompok tani dalam pertemuan kelompok atau kepada petani secara personal. Hasil penelitian ini 
didukung dengan penelitian yang dilakukan oleh Krisnawati (2014), yaitu seorang penyuluh pertanian adalah sumber informasi atau komunikator dalam kegiatan penyuluhan pertanian.

b) Petani

Selain PPL, informasi yang diterima oleh anggota kelompok tani juga berasal dari petani lainnya pada saat melakukan pertemuan atau pada saat pertemuan tidak resmi. Petani yang tergabung dalam kelompok tani juga menjadi komunikator dalam kegiatan penyuluhan pertanian. Seringnya sesama petani bertemu juga mempengaruhi prilaku petani lainnya dalam menerapkan metode baru. Semua petani bisa menjadi sumber informasi dalam kegiatan penyuluhan pertanian. Petani yang menjadi komunikator juga merupakan penduduk setempat, sehingga ada kesamaan latar belakang dan cara pandang yang memudahkan dalam penerimaan informasi yang disampaikan. Hasil dari penelitian yang dilakukan oleh Syahyuti, (2014) yang menyatakan bahwa dibutuhkan bantuan petani lainnya sebagai sumber informasi atau komunikator.

c) Petugas Formulator Pestisida

Petugas formulator pestisida juga menjadi penyuluh pertanian swasta. Petugas formulator pestisida, pada umumnya memberikan informasi yang berhubungan dengan produk yang dihasilkan. Petugas formulator pestisida menyampaikan informasi langsung kepada anggota kelompok tani pada saat pertemuan kelompok. Petugas formulator pestisida juga mengenalkan dan memasarkan obat-obat pertanian seperti pestisida guna memberikan hasil yang maksimal dalam melakukan budidaya padi pada kelompok tani. Hal ini didukung dengan hasil penelitian yang dilakukan oleh Sari (2016), yang menyatakan bahwa kepuasan petani terhadap penyuluh pertanian swasta dalam mengembangkan komoditi yang dilakukan yang diperoleh dari setiap aspek yaitu sebagai komunikator atau sumber informasi.

\section{Pesan Penyuluhan Pertanian}

Pesan dalam komunikasi pertanian adalah semua informasi yang berkaitan dengan bidang pertanian (Soekartawi, 1988). Pesan penyuluhan pertanian merupakan sesuatu yang disampaikan untuk anggota kelompok tani dalam kegiatan penyuluhan pertanian. Pesan tersebut disampaikan oleh PPL pada anggota kelompok tani yang meliputi dengan program metode sistem tanam SRI dengan kegiatan sekolah lapang (SL). Sekolah lapang ini juga terdapat pelatihannya dalam bentuk pertemuan dalam kegiatan penyuluhan pertanian. Sekolah lapang juga merupakan bagian dari program pemerintah pusat yang diturunkan langsung kepada anggota kelompok tani melalui Dinas Pertanian. Sekolah lapang pertanian tersebut dinamakan SL-PTT (Sekolah Lapangan Pengelolaan Tanaman Terpadu). Pesan yang lain yang disampaikan oleh PPL yaitu berkaitan tentang menerapkan metode tanam yang benar, jenis padi hibrida dan padi lokal, pemupukan organik dan pembuatan MOL. Pembuatan MOL yaitu pelatihan dalam membuat bahan dekomposer dan pupuk cair yang berasl dari bonggol pisang dan dedaunan.

Pesan penyuluhan pertanian yang disampaikan juga harus didasarkan dan disesuaikan dengan permintaan dan kebutuhan dari anggota kelompok tani. Pesan yang disampikan dalma penyuluhan pertanian yaitu pengamatan hama, setelah panen dan menjelang panen yaitu evaluasi. Selain itu, pesan yang disampaikan dalam kegiatan penyuluhan pertanian yaitu berkaitan yang sesuai dengan kondisi 
dan keadaan lapang. Berdasarkan hasil dari penelitian dari, yang menyatakan bahwa materi penyuluhan yang di butuhkan oleh petani harus di dasarkan pada kesempatan, kemauan dan kemampuan petani. Selain itu, pesan penyuluhan pertanian yang disampaikan oleh PPL harus sesuai dengan kondisi dan keadaan lapang. Menurut Puspitasari (2019), hal tersebut dilakukan untuk memudahkan petani dalam mempelajari materi yang disampaikan. Hasil penelitian yang dilakukan oleh Rintjap (2015), menyatakan bahwa materi penyuluhan yang disampaikan harus sesuai dengan kebutuhan sasarannya.

\section{Saluran Komunikasi Penyuluhan Pertanian}

Media komunikasi merupakan saluran komunikasi yang dapat menyapaikan pesan berupa informasi yang diperlukan. Media komunikasi merupakan bagian penting dari komunikasi yang berlangsung, karena berhubungan erat dengan pesan-pesan yang disampaikan. Hasil penelitian yang telah dilakukan berkaitan dengan saluran komunikasi diantaranya yaitu melalui saluran atau media antar pribadi (Interpersonal). Berikut penjelasan saluran komunikasi yang diperoleh dari hasil wawancara :

a) Tatap Muka

Saluran komunikasi merupakan bagian dari proses komunikasi yang terjadi dalam masyarakat. Saluran komunikasi penyuluhan pertanian pada Kelompok Tani Barokah yaitu secara langsung (tatap muka). Petani mendapatkan informasi kapan saja dan dimana saja seputar pertanian. Pada saat petani bertemu baik di sawah maupun dimana saja, mereka dapat saling bertukar informasi. Saluran komunikasi langsung terjadi diantara petani dengan petani ataupun petani dengan PPL. Penyampaian materi secara langsung dapat diterima dan diaplikasikan oleh anggota kelompok tani dengan efektif dan efisien. Selain itu, penyampaian materi secara langsung juga agar tidak terjadi kesalahpahaman dalam berkomunikasi.

b) Telepon (Handphone)

Saluran komunikasi antar pribadi lainnya adalah telepon (HP). Telepon digunakan sebagai alat komunikasi pada hal-hal tertentu yang sulit dilakukan dalam situasi tatap muka. Telepon merupakan alat yang berguna dan lebih efektif untuk melakukan kegiatan penyuluhan pertanian. Anggota kelompok tani juga menggunak HP sebagai media komunikasi dalam melakukan kegiatan pertukaran informasi. Jika petani mengalami kesulitan maka petani sesegera akan menghubungi petani lainnya. Ketua kelompok tani juga bisa menghubungi penyuluh dan menyampaikan permasalahan yang dihadapi agar mendapatkan solusi pemecah masalah. Petani juga dapat bertanya langsung melalui sms atau menelepon dengan PPL. Penggunaan media komunikasi berupa telepon juga sudah mengikuti arus zaman saat ini.

c) Pertemuan Kelompok

Kegiatan penyuluhan pertanian dilakukan melalui pertemuan kelompok. Pertemuan kelompok yang dilakukan dengan memberikan pengarahan kepada anggota kelompok tani. Pertemuan kelompok berperan dalam mengaktifkan anggota kelompok tani. Pertemuan kelompok didalamnya juga terdapat dinamika kelompok, dialog dan diskusi. Pertemuan kelompok yang dilakukan dengan memberikan pengarahan kepada anggota kelompok tani. Pertemuan kelompok tani dilakukan satu bulan sekali. Pertemuan kelompok tani dilakukan karena terdapat umpan balik antar PPL dan petani yang mengikuti penyuluhan pertanian. Berdasarkan hasil dari penelitian yang dilakukan oleh Rasyid (2012), menyatakan bahwa metode dengan pendekatan kelompok lebih menguntungkan karena adanya umpan balik. 


\section{Komunikan Penyuluhan Pertanian}

Keberadaan kelompok tani di Indonesia telah lama ada sebagai lembaga komunikasi antar petani dalam menjalankan aktivitasnya. Kelompok tani diartikan sebagai kumpulan petani yang terikat secara informal atas dasar keserasian dan kepentingan bersama dalam usahatani. Kelompok tani yang ada saat ini menunjukan banyak peran penting dalam penyelenggaraan program pembangunan pertanian. Kelompok tani juga memainkan berbagai peran, diantaranya sebagai forum belajar berusahatani dan berorganisasi, wahana kerjasama, dan unit produksi usahatani. Selain itu, kelompok tani juga berperan dalam memberi umpan balik tentang kinerja suatu teknologi, sehingga menjadi bahan evaluasi untuk perbaikan lebih lanjut (Nuryanti \& Swastika, 2011). Komunikan adalah orang yang menerima ide, gagasan, atau informasi dari komunikator. Komunikan juga bisa disebut dengan istilah penerima pesan, khalayak, sasaran, audience dan lain sebagainya. Komunikan merupakan salah satu faktor dalam proses komunikasi. Unsur komunikan dalam suatu proses komunikasi tidak boleh diabaikan karena berhasil tidaknya proses komunikasi sangat ditentukan oleh komunikan. Karena itu, sebelum memulai proses komunikasi seorang komunikator harus mengetahui siapa dan bagaimana sasaran.

Komunikan adalah pihak yang menerima pesan, komunikan bisa individu maupun kelompok, organisasi atau lainnya. Komunikan dalam penyuluhan pertanian adalah Kelompok Tani Barokah, baik ketua kelompok tani maupun dari anggota-anggotanya dari kelompok tani. Kelompok tani tersebut adalah salah satu kelompok yang berada di Desa Rowotengah Kecamatan Sumberbaru Kabupaten Jember Provinsi Jawa Timur.

\section{Efek Komunikasi Penyuluhan Pertanian}

Komunikasi yang efektif mampu memunculkan kesamaan makna pesan atau informasi antara pengirim dan penerima. Komunikasi penyuluhan dapat dikatakan efektif apabila pesan yang disampikan penyuluh dapat diterima dengan baik dan mampu menimbulkan perubahan perilaku di kalangan petani. Perubahan perilaku petani mengandung tiga ranah yang digunakan sebagai indikator efektivitas komunikasi yaitu kognitif, afektif, dan behavioral (Saefudin, 2016). Efek komunikasi merupakan respon penerima terhadap pesan-pesan yang diterima dan merupakan umpan balik (feedback) bagi komunikator atas pesan-pesan yang disampaikan. Efek komunikasi berupa perubahan-perubahan yang diharapkan terjadi pada sasaran akibat dari proses komunikasi. Efek komunikasi ada yang langsung bisa diketahui, misalnya perubahan pengetahuan dan keterampilan, akan tetapi ada pula yang tidak langsung artinya memerlukan waktu yang lama misalnya perubahan sikap dan kepribadian. Tujuan penyuluhan pertanian ini adalah agar supaya masyarakat petani di kelompok tani dapat menerima informasi, merasakannya, menerapkan dan memanfaatkan ketika semua informasi telah disampaikan sebagimana mestinya dari peran seorang peenyuluh di dalam kehidupan sehai-hari. Hasil penelitian yang telah dilakukan berkaitan dengan efek komunikasi penyuluhan pertanian sebagai berikut ini: a) Efek Kognitif

Efek komunikasi dari aspek kognitif dalam kegiatan penyuluhan pertanian adalah meningkatakan pengetahuan dan wawasan dari anggota kelompok tani. Informasi yang disampaikan oleh komunikator ditujukan kepada pemikiran dari komunikan. Kegiatan penyuluhan pertanian efektif untuk meningkatkan 
pengetahuan dan wawasan dari anggota kelompok tani dalam usahatani. Pengetahuan dan wawasan mengenai usahatani membantu memahami kejadiankejadian sekitar, serta membantu menjawab keingintahuan anggota kelompok tani dalam masalah pertanian. Hasil dari penelitian bahwa kegiatan penyuluhan pertanian yang dilakukan pada anngota kelompok tani memberikan tambahan pengetahuan dan mengetahui dengan metode sistem tanam SRI. Berdasarkan hasil dari penelitian yang telah dilakukan oleh Saefudin (2016), dampak kognitif merupakan adanya peningkatan pengetahuan para petani dalam masalah usahataninya.

b) Efek Afektif

Efek komunikasi dari aspek afektif dalam kegiatan penyuluhan pertanian adalah perubahan sikap dan pandangan dari anggota kelompok tani. Informasi yang disampaikan dalam kegiatan penyuluhan pertanian oleh komunikator ditujukan untuk menggerakan hati anggota kelompok tani dan menimbulkan perasaan tertentu. Hasil dari penelitian yang telah dilakukan bahwa kegiatan penyuluhan pertanian yang dilakukan pertama kali sikap petani yaitu adanya penolakan, hal ini didasari atas kurangnya percontohan hasil yang telah dibuktikan. Selain itu, kegiatan penyuluhan pertanian sangat dibutuhkan oleh anggota kelompok tani dikarenakan dapat memberikan pertukaran informasi berkaitan dengan pertanian. Perubahan sikap dari anggota kelompok tani yaitu berupa mau menerima dan menerapkan dari penyampaian informasi dalam kegiatan penyuluhan pertanian. Berdasarkan hasil dari penelitian dari Saefudin (2016), menyatakan bahwa adanya kegiatan penyuluhan pertanian mampu meningkatkan minat para petani dan sikap petani dalam menjalankan usahataninya.

c) Efek Konatif

Efek konatif yaitu perubahan perilaku atau tindakan yang terjadi pada komunikan. efek konatif berhubungan dengan perilaku dan niat untuk melakukan sesuatu dengan cara tertentu. Kegiatan penyuluhan pertanian yang paling efektif dalam efek konatif yaitu keinginan petani untuk menjalankan saran dari penyuluh dan menerapkan informasi yang telah disampikan dalam kegiatan penyuluhan pertanian. Hasil dari penelitian yang telah dilakukan menjelaskan bahwa anggota kelompok tani yang sukses akan terus menerapkan metode sistem tanam SRI dan anggota kelompok tani yang baru mencoba menerapkan yang belum sukses akan kembali ke konvensional. Hal ini didukung dengan hasil penelitian yang telah dilakukan oleh Saefudin (2016), yang menyatakan bahwa perubahan prilaku dan tindakan yang terjadi dari anggota kelompok tani dari setelah mengikuti kegiatan penyuluhan pertanian.

\section{KESIMPULAN}

Komunikator pada penyuluhan pertanian pada kelompok tani Barokah Desa Rowotengah Kecamatan Sumberbaru Kabupaten Jember adalah Penyuluh Pertanian Lapangan (PPL), Petani, dan Petugas Formulator Pestisida. Materi penyuluhan pertanian adalah pesan yang disampikan oleh seorang penyuluh pertanian kepada sasarannya dalam proses komunikasi yang berlangsung. Materi yang disampaikan harus sesuai dengan kebutuhan sasaran dan keadaan serta kondisi lapang yang terjadi. Media komunikasi dalam penyuluhan pertanian pada anggota kelompok tani adalah menggunakan saluran antar pribadi yang terbagi menjadi tatap muka, HP 
(Handphone), dan pertemuan kelompok. Komunikan pada penyuluhan pertanian di Desa Rowotengah Kecamatan Sumberbaru Kabupaten Jember Jawa Timur yaitu Kelompok Tani Barokah, baik ketua kelompok ataupun anggota dari Kelompok Tani Barokah. Efek Komunikasi yang diterima dari penyampaian materi yaitu efek kognitif berupa bertambahnya pengetahuan dan wawasan. Efek afektif berupa perubahan sikap dan pandangan dari para petani. Efek konatif berupa tindakan petani dalam mengaplikasikan materi penyuluhan pertanian yang telah didapatkan.

\section{DAFTAR PUSTAKA}

Batlayeri, M., Adam, F. P., \& Far-Far, R. A. (2013). Tingkat Kepuasan Petani Terhadap Penyuluhan Pertanian pada Desa Waiheru Kecamatan Kota Ambon. Agribisnis Kepulauan, 3(1), 81-94.

Elian, N. (2015). Penggunaan Internet dan Pemanfaatan Informasi Pertanian Oleh Penyuluh Pertanian di Wilayah Barat Kabupaten Bogor. Institut Pertanian Bogor.

Krisnawati. (2014). Persepsi Petani Terhadap Peranan Penyuluh Pertanian di Desa Sidomulyo dan Muari Distrik Oransbari Kabupaten Manokwari Selatan. Institut Pertanian Bogor.

Nuryanti, S., \& Swastika, D. K. S. (2011). Peran Kelompok Tani dalam Penerapan Teknologi Pertanian. Forum Penelitian Agro Ekonomi, 29(2), 115-128. https://doi.org/10.21082/fae.v29n2.2011.115-128

Puspitasari, P. F. (2019). Efektivitas Penyuluhan Terhadap Perilaku Petani Kopi Di Desa Sidomulyo Kecamatan Silo Kabupaten Jember. Universitas Jember.

Rasyid, A. (2012). Metode Komunikasi Penyuluhan Pada Petani Sawah. Jurnal Ilmu Komunikasi, 1(1), 1-55.

Ratnasari, R. T. (2015). Mengkombinasikan Jajar Legowo dan SRI. Tabloid Sinartani.

Rintjap, A. K. (2015). Efektivitas komunikasi dalam penerimaan informasi pada kelompok peternak sapi potong di Kecamatan Remboken, Kabupaten Minahasa, Sulawesi Utara. Pros Sem Nas Masy Biodiv Indon, 1(7), 1711-1714. https://doi.org/10.13057/psnmbi/m010733

Saefudin, N. K. (2016). Efektivitas Komunikasi Penyuluhan Pertanian di Tingkat Kelompok Tani Desa Margahayu Kecamatan Manonjaya Kabupaten Tasikmalaya Jawa Barat. Institut Pertanian Bogor.

Sari, O. (2016). Analisis Kepuasan Petani Terhadap Peran Penyuluh Pertanian Swasta (PT. TRI BERKAT AGRO) Dalam Mengembangkan Komoditi Hortikultura di Kecamatan Lembah Gumanti Kabupaten Solok. Universitas Andalas.

Soekartawi. (1988). Prinsip dasar komunikasi pertanian. Jakarta: Penerbit Universitas Indonesia (UI Press).

Syahyuti. (2014). Peran Strategis Penyuluh Swadaya dalam Paradigma Baru Penyuluhan Pertanian Indonesia. Forum Penelitian Agro Ekonomi, 32(1), 4358. https://doi.org/10.21082/fae.v32n1.2014.43-58

Undang-undang Republik Indonesia Nomor 16 Tahun 2006 Tentang Sistem Penyuluhan Pertanian, Perikanan dan Kehutanan (SP3K). (2006). Undang Undang Republik Indonesia Nomor 16 Tahun 2006, pp. 1-39. 